\title{
Implementation of Stereotactic Accelerated Partial Breast Irradiation Using Cyber-Knife - Technical Considerations and Early Experiences of a Phase II Clinical Study
}

\author{
Norbert Mészáros $^{1,2}$ (1) V Viktor Smanykó ${ }^{1} \cdot$ Tibor Major $^{1,2} \cdot$ Gábor Stelczer $^{1} \cdot$ Levente Jánváry $^{1} \cdot$ Eszter Kovács $^{3}$. \\ Bahéri Mária $^{3}$ - Zoltán Zaka ${ }^{1}$ - Dávid Pukancsik ${ }^{4}$ - Zoltán Takácsi-Nagy ${ }^{1,2} \cdot$ Csaba Polgár $^{1,2}$
}

Received: 20 October 2019 / Accepted: 12 May 2020 / Published online: 29 May 2020

(C) The Author(s) 2020

\begin{abstract}
To report the implementation, dosimetric results of and early experiences with stereotactic accelerated partial breast irradiation (SAPBI) following breast conserving surgery (BCS) for postmenopausal low-risk St I-II invasive breast cancer (IBC) patients. Between November 2018 and August 2019, 27 patients were registered in our phase II prospective study. SAPBI was performed with Cyber-Knife (CK) M6 machine, in 4 daily fractions of 6.25 Gy to a total dose of 25 Gy. Respiratory movements were followed with implanted gold markers and Synchrony system. Corrections for patient displacement and respiratory movement during treatment were performed with the robotic arm. Early side effects, cosmetic results, and dosimetric parameters were assessed. The average volume of the surgical cavity, clinical target volume (CTV), and planning target volume (PTV EVAL) were $8.1 \mathrm{~cm}^{3}$ (range: $1.75-27.3 \mathrm{~cm}^{3}$ ), $55.3 \mathrm{~cm}^{3}$ (range: $26.2-103.5 \mathrm{~cm}^{3}$ ), and $75.7 \mathrm{~cm}^{3}$ (range: $40-135.4 \mathrm{~cm}^{3}$ ), respectively. The mean value of the PTV_eval/whole breast volume ratio was 0.09 (range: 0.04-0.19). No grade 2 or worst acute side-effect was detected. Grade 1 (G1) erythema occurred in $6(22.2 \%)$ patients, while G1 oedema was reported by $3(11.1 \%)$ cases. G1 pain was observed in 1 (3.4\%) patient. Cosmetic result were excellent in 17 (62.9\%) and good in 10 (37.1\%) patients. SAPBI with CK is a suitable and practicable technique for the delivery of APBI after BCS for low-risk, St. I-II. IBC. Our early findings are encouraging, CK-SAPBI performed with four daily fractions is convenient and perfectly tolerated by the patients.
\end{abstract}

Keywords Breast cancer $\cdot$ APBI $\cdot$ SBRT $\cdot$ Cyber-knife $\cdot$ Phase II

\section{Introduction}

The most frequent malignancy among women in industrialized countries is breast cancer (BC). According the WHO 627,000 women died from $\mathrm{BC}$ worldwide - which is almost 15\% of all cancer deaths among women in 2018 (https://www.

Norbert Mészáros

meszarosnorbert@oncol.hu

1 Center of Radiotherapy, National Institute of Oncology, Ráth György u. 7-9, Budapest H-1122, Hungary

2 Department of Oncology, Semmelweis University, Faculty of Medicine, Budapest, Hungary

3 Department of Radiology, National Institute of Oncology, Budapest, Hungary

4 Department of Breast and Sarcoma Surgery, National Institute of Oncology, Budapest, Hungary who.int/cancer/prevention/diagnosis-screening/breast-cancer/ en/). Due to the introduction of mammography screening and more effective oncological treatments, $\mathrm{BC}$ mortality shows a downward trend. Several prospective randomized studies demonstrated that in early-stage BC patients whole breast irradiation (WBI) following breast conserving surgery (BCS) not only reduces the proportion of local recurrences (LR) in the ipsilateral breast, but also improves overall survival [1-3]. The rationale for WBI is the eradication of residual microscopic disease after lumpectomy. However, WBI exposes the skin, lung, chest wall, and heart to high doses of radiation. The theory of accelerated partial breast irradiation (APBI) stems from two reasons. First, the predominance of LR's after $\mathrm{BCS}$ are near to the original primary tumour site. According to the pathological studies of Holland et al., multicentricity occurred in a significant proportion of BC's, therefore, WBI was the standard treatment after BCS [4]. Later, other pathological studies demonstrated that in a unicentric, unifocal tumour (without extensive intraductal component or invasive lobular 
pathological subtype), microscopic tumour cells can be found only in $2-4 \%$ at $>1.5-2 \mathrm{~cm}$ distance from the index tumour, and following WBI the ipsilateral breast recurrence rate was almost equivalent to the rate of contralateral carcinomas $[5,6]$. Second, even in developed countries, radiotherapy units are not available in all cities, therefore, the five-days-a-week occasions for 3 to 7 weeks treatment schedule may expect patients to omit work and can lead to other daily routine severances. Almost $20 \%$ of patients with early-stage IBC and treated with BCS choose to forgo the radiation therapy in the United States [7]. To minimalize the treatment schedule from 3 to 7 weeks to 1 week or less is another advantage of APBI. These pathological findings and the clinical eagerness to abbreviate the course of breast radiotherapy and decrease the toxicity of normal tissues led to the investigation of efficacy and safety of APBI in prospective clinical trials [8-25]. In these early studies, the inappropriate patient selection criteria, quality control, and target definition led to very high (25$37 \%$ ) local relapse rates after 6-8 years [8,9]. In later studies, more favourable experiences accumulated using APBI with interstitial brachytherapy (iBT), three-dimensional conformal external beam radiotherapy (3D-CRT), and image-guided intensity-modulated radiotherapy (IG-IMRT) in correctly selected early-stage BC patients [10-25]. Stereotactic treatment approaches are emerging and are widely accepted in early stage lung cancer, prostate cancer, or bone and brain metastasis patients [26-29]. However, to date, only a few phase I/II studies were published with CyberKnife-based stereotactic APBI (CK-SAPBI) [30-36].

In 2018, we initiated a phase II clinical study to test the effectiveness and usefulness of CK-SAPBI with a fourfraction schedule. SAPBI adopting real-time tracking, respiratory motion administration, and submillimetre efficiency offers improvements in partial breast irradiation enabling great dose conformality to target region $[31,36]$. We report the dosimetric parameters and the early clinical outcomes of this prospective phase II clinical study using CK-SAPBI.

\section{Patients and Methods}

Between 2018 November and 2019 August, 27 earlystage BC patients were treated with CK-SAPBI. Patient eligibility criteria were the same as in our previous APBI trials, and were reported in detail in our previous publications [19, 20, 22, 23]. Briefly, patients were eligible for CK-SAPBI if they were 50 years old or older, with invasive tumour up to a diameter of $3 \mathrm{~cm}$, with negative axillary lymph node status (pN0) and with clear surgical margins by at least $2 \mathrm{~mm}$. We omitted patients if they had multiple or multifocal invasive tumour histology subtype Paget-disease, bilateral breast cancer, preliminary history of $\mathrm{BC}$ or additional malignant disease within
5 years. Tumour and patient characteristics are presented in Table 1 . To identify the excision cavity and to guide optimal fiducial placement, CT scanning of the operated breast was performed with a $5 \mathrm{~mm}$ slice thickness. Only patients with good identifiable cavity were eligible for the study (visibility score (CVS) of 3-5) [37]. Prior to the treatment, three to four gold fiducials were placed near the surgical bed with ultrasound guidance by a certified radiologist together with the treating radiation oncologist, in local anaesthesia. For optimal tracking, the maximum and minimum distances between fiducial markers were less than $10 \mathrm{~cm}$ and more than $2 \mathrm{~cm}$, and the markers were placed at least $1-2 \mathrm{~cm}$ away from the seroma cavity, as recommended by Seiler et al. [38]. One week after gold marker placement, a new simulation CT was performed in a supine position with both arms next to the body with $1.25 \mathrm{~mm}$ axial slice spacing. For delineating the target volumes and organs at risks, the GEC-ESTRO Breast Working Group recommendations were applied [39]. The surgical bed included the surgical clips were determined as the tumour bed. The clinical target volume (CTV) was defined as the tumour bed $+(20 \mathrm{~mm}$ minus the free surgical margins (in $\mathrm{mm}$ )) in six directions. The CTV margin was confined at the breast parenchyma/ pectoral muscle interface and to $5 \mathrm{~mm}$ beneath the skin surface and. A uniform, three-dimensional $2 \mathrm{~mm}$ margin was added to the CTV to attain the planning target volume (PTV). For dosimetric reporting, the PTV_EVAL was accomplished from the PTV limiting the PTV except the first $5 \mathrm{~mm}$ of tissue from surface and any lung tissue [15]. Daily localization and fiducial tracking were accomplished with the Synchrony Respiratory Tracking System (Cyberknife, Accuray, Sunnyvale, CA). Light-emitting diodes (LED's) were placed on the chest wall of the patients and were tracked by an optical camera. Fifteen orthogonal $\mathrm{x}$-ray image pairs were acquired in different phases of the breathing cycle. The fiducials were checked on each image pair. A predictive correlation model was created between tumour bed positions - represented by the fiducials - and the chest wall position. During beam delivery, the radiation fields were always pointing at the position of the PTV, according to the information obtained from the optical camera signal. A minimum of 3 fiducial markers were tracked at all times to avoid rotational errors. The treatments were performed on a CyberKnife M6 machine with MLC and step-and-shoot IMRT technique, with 57 segments on average (range: 34-76), and with a dose of $4 \times 6.25$ Gy (total dose: 25 Gy) on four consecutive days (Figs. 1 and 2). Our equivalent dose calculations are listed in Table 2, compared to other fractionations $(10 \times 3.4 \mathrm{~Gy}$ and $7 \times 4.3 \mathrm{~Gy}$ ) frequently used by others in routine clinical practice. Radiotherapy was started within 12 weeks after surgery for all 27 patients. Hormone therapy was 
Table 1 Patient, tumor and adjuvant treatment characteristics

\begin{tabular}{|c|c|}
\hline Characteristics & $\mathrm{n}(\%)^{\mathrm{a}}$ \\
\hline Mean age (range) & 65 ys. $(50-77)$ \\
\hline \multicolumn{2}{|l|}{ Age groups (years) } \\
\hline $50-60$ & $5(18.5 \%)$ \\
\hline $61-70$ & $17(63 \%)$ \\
\hline$>70$ & $5(18.5 \%)$ \\
\hline Postmenopausal & $26(96.3 \%)$ \\
\hline \multicolumn{2}{|l|}{ Breast cup size } \\
\hline A & $7(25.9 \%)$ \\
\hline B & $6(22.2 \%)$ \\
\hline $\mathrm{C}$ & $12(44.4 \%)$ \\
\hline $\mathrm{D}, \mathrm{D}+$ & $2(7.5 \%)$ \\
\hline \multicolumn{2}{|l|}{ Laterality } \\
\hline Right & $14(51.8 \%)$ \\
\hline Left & $13(48.2 \%)$ \\
\hline \multicolumn{2}{|c|}{ Tumour location (quadrant) } \\
\hline Upper-outer & $15(55.6 \%)$ \\
\hline Lower-outer & $4(14.7 \%)$ \\
\hline Upper-inner & $5(18.6 \%)$ \\
\hline Lower-inner & $1(3.6 \%)$ \\
\hline Central & $2(7.5 \%)$ \\
\hline \multicolumn{2}{|c|}{ Pathological tumour size (mm) } \\
\hline$\leq 5$ & $0(0 \%)$ \\
\hline$>5-10$ & $12(44.4 \%)$ \\
\hline$>10-20$ & $13(48.2 \%)$ \\
\hline$>20-30$ & $2(7.4 \%)$ \\
\hline Median (mm) & 10 \\
\hline \multicolumn{2}{|c|}{ Pathological nodal status } \\
\hline pN0 (SLNB) & $27(100 \%)$ \\
\hline pN0 (ALND) & $0(0 \%)$ \\
\hline \multicolumn{2}{|c|}{ Free surgical margins $(\mathrm{mm})$} \\
\hline$\geq 2-5$ & $12(44.4 \%)$ \\
\hline$>5-10$ & $15(55.6 \%)$ \\
\hline$>10$ & $0(0 \%)$ \\
\hline \multicolumn{2}{|l|}{ Histologic type } \\
\hline Ductal invasive & $27(100 \%)$ \\
\hline \multicolumn{2}{|l|}{ Histologic grade } \\
\hline 1 & $13(48.2 \%)$ \\
\hline 2 & $13(48.2 \%)$ \\
\hline 3 & $1(3.6 \%)$ \\
\hline \multicolumn{2}{|c|}{ Hormone receptor status } \\
\hline $\mathrm{ER}$ and $\mathrm{PR}+$ & $26(96.4 \%)$ \\
\hline $\mathrm{ER}+, \mathrm{PR}-$ & $1(3.6 \%)$ \\
\hline $\mathrm{ER}-, \mathrm{PR}+$ & $0(0 \%)$ \\
\hline ER and PR - & $0(0 \%)$ \\
\hline \multicolumn{2}{|l|}{ Endocrine therapy } \\
\hline Yes & $27(100 \%)$ \\
\hline No & $0(0 \%)$ \\
\hline \multicolumn{2}{|l|}{ Chemotherapy } \\
\hline Yes & $0(0 \%)$ \\
\hline No & $27(100 \%)$ \\
\hline
\end{tabular}

$E R$ estrogen receptor, $P R$ progesterone

${ }^{a}$ receptor Data are $\mathrm{n}(\%)$ if not otherwise specified

applied to all patients, 26 patients $(96.6 \%)$ received aromatase inhibitors or goserelin acetate and tamoxifen in 1 case $(3.4 \%)$. Within 7-14 days after the completion of CK-SAPBI, the acute side effects were recorded according to the Radiation Therapy Oncology Group/European Society for Therapeutic Radiology and Oncology (RTOG/EORTC) scoring system [40].

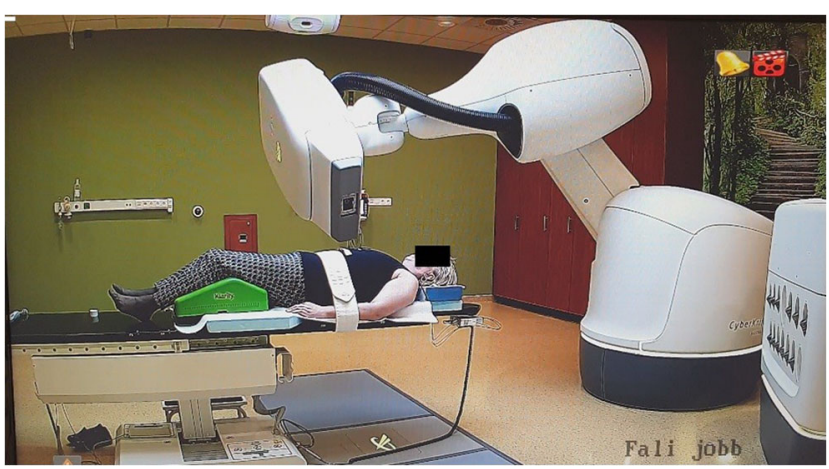

Fig. 1 S-APBI with M6 Cyberknife machine

The study protocol was assessed and approved by the national ethics committee, and before recruitment all women provided written informed consent.

\section{Results}

All patients received the planned four fractions of CK-SAPBI with the predefined study-specific dose constraints. No protocol violation arose. At least three fiducials were tracked in all cases. The mean size of the primary tumour was $11 \mathrm{~mm}$ (range: 6-21 mm). The average volume of the surgical cavity, CTV and PTV_EVAL was $8.1 \mathrm{~cm}^{3}$ (range: $1.75-27.3 \mathrm{~cm}^{3}$ ), $55.3 \mathrm{~cm}^{3}$ (range: $26.2-103.5 \mathrm{~cm}^{3}$ ), and $75.7 \mathrm{~cm}^{3}$ (range: 40 $135.4 \mathrm{~cm}^{3}$ ), respectively. The mean value of the PTV_eval/ whole breast volume ratio was 0.09 (range: $0.04-0.19$ ). Dosevolume parameters are listed in Table 3. The average values of V100 for CTV and PTV_EVAL were $99.4 \%$ and $97.5 \%$, respectively. The mean Dmax value for PTV_EVAL was $116.5 \%$. The mean $\mathrm{V}_{100}, \mathrm{~V}_{75}$ and $\mathrm{V}_{50}$ of ipsilateral breastPTV was $0.73 \%$ (range: $0.3-1.4$ ), $4.8 \%$ (range: $2-8.5 \%$ ) and $10.8 \%$ (range: $5-18.9 \%$ ) respectively. The mean ipsilateral and contralateral lung dose (MLD) and $\mathrm{D}_{10 \%}$ was $131 \mathrm{cGy}$ (range: 33-205 cGy) and 328 cGy (range: 68-524 cGy), 12 cGy (range: 3-44 cGy) and 29 cGy (range: 8-131 cGy), respectively. The mean heart dose (MHD) and $\mathrm{D}_{0,04 \mathrm{~cm} 3}$ heart was 89 cGy (range: 31-173 cGy) and 568 cGy (range: 2161094 cGy) for left-sided, and 34 cGy (range: 13-84 cGy) and 219 cGy (range: 90-436 cGy) for right-sided lesions, respectively. The mean $\mathrm{D}_{0,01 \mathrm{~cm}}{ }^{3}$, and mean $\mathrm{D}_{0,04 \mathrm{~cm} 3}$ skin and rib doses was 2380 cGy (range: 1074-2866 cGy), 2338 cGy (range: 1021-2839 cGy) and 2317 cGy (range: 978-2766), 2243 cGy (range: 952-2722 cGy) respectively. A typical treatment plan are shown in Fugure 2.

At a median follow-up of 12 months (range: 8-17 months), no loco-regional recurrence or distant metastasis occurred, and all patients are alive. Grade 2 or worse early side-effect wasn't detected. Grade 1 (G1) erythema occurred in $6(22.2 \%)$ patients, while G1 oedema, was reported in $3(11.1 \%)$ cases. G1 pain was observed by $1(3.4 \%)$ patient. The cosmetic 

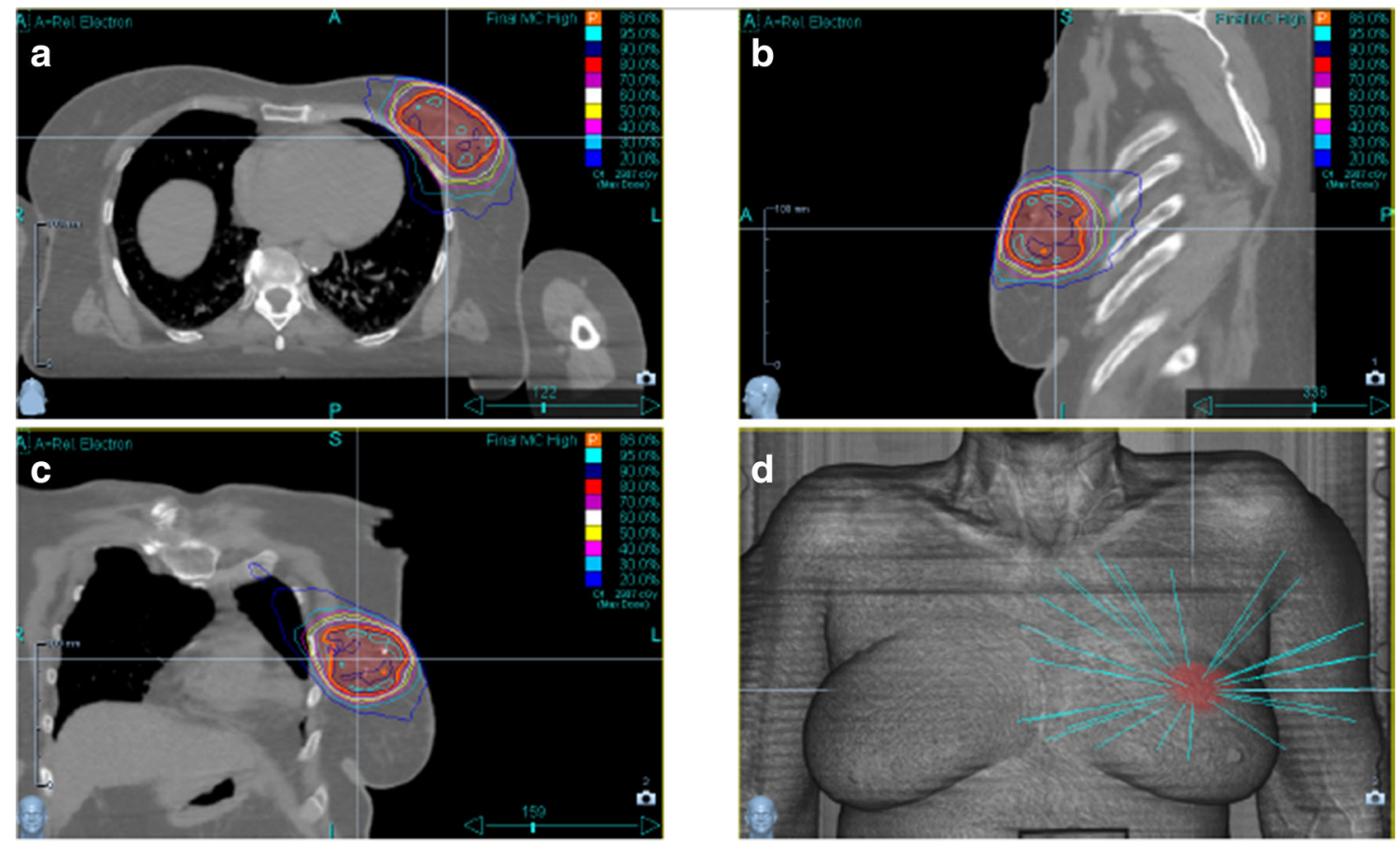

Fig. 2 Cyber-Knife treatment planning images with the dose of $4 \times 6.25$ Gy. a-c isodose lines in three different planes. d illustration of pencil beam trajectories

outcome was excellent in $17(62.9 \%)$, and good in $10(30.1 \%)$ patients. Cosmetic results and early side effects are listed in Table 4. The average daily treatment time was 43 min (range: 33-68 min) door-to-door.

\section{Discussion}

At our institute, between November 2018 and August 2019, 27 patients were treated with SAPBI using a Cyber-Knife M6 machine, with four daily fractions. According to our early experience, no patients have recurrence or fair/poor cosmesis.

APBI with appropriate patient selection and quality control became a widely accepted treatment option for the treatment of early-stage $\mathrm{BC}$ in highly qualified radiotherapy centres [10-25]. In the GEC-ESTRO Breast Cancer Working Group, multicentric randomised study iBT still prove the

Table 2 Calculations of equivalent doses in different fractionations with using different $\alpha / \beta$ ratio

\begin{tabular}{llllll}
\hline & Total dose & $\mathrm{BED} \mathrm{Gy}_{4}$ & $\mathrm{BED} \mathrm{Gy}_{10}$ & $\mathrm{BED} \mathrm{Gy}$ & EQD2 Gy \\
\hline $10 \times 3.4 \mathrm{~Gy}$ & 34 & 63 & 46 & 92 & 42 \\
$7 \times 4.3 \mathrm{~Gy}$ & 30.1 & 63 & 43 & 96 & 41.6 \\
$4 \times 6.25 \mathrm{~Gy}$ & 25 & 64 & 40.6 & 103 & 42.7 \\
\hline
\end{tabular}

Biological equivalent dose (BED) and equivalent dose in 2 Gy per fraction (EQD2) for tumour control and for normal tissue toxicity at each dose level
Table 3 Dose volumes parameters of organs at risks

\begin{tabular}{|c|c|c|}
\hline \multirow[t]{2}{*}{ Organs at risks } & \\
\hline & Mean & Median (range) \\
\hline \multicolumn{3}{|c|}{ Ipsilateral non-target breast (\%) } \\
\hline V $100 \%$ & 0.7 & $0.7(0.3-1.4)$ \\
\hline $\mathrm{V} 75 \%$ & 4.8 & $4.3(2.0-8.5)$ \\
\hline V $50 \%$ & 10.7 & $9.5(5-18.9)$ \\
\hline \multicolumn{3}{|l|}{ Contralateral breast } \\
\hline D 0.04 cm3 (cGy) & 50.4 & $39(13-172)$ \\
\hline \multicolumn{3}{|l|}{ Mean dose (cGy) } \\
\hline \multicolumn{3}{|l|}{ Heart (left sided lesion) } \\
\hline D 0.04 cm3 (cGy) & 568 & 477 (216-1094) \\
\hline Mean dose (cGy) & 89 & $83(31-173)$ \\
\hline \multicolumn{3}{|c|}{ Heart (right sided lesion) } \\
\hline D 0.04 cm3 (cGy) & 219 & $201(90-436)$ \\
\hline Mean dose (cGy) & 34 & $33(13-84)$ \\
\hline \multicolumn{3}{|l|}{ Ipsilateral lung } \\
\hline D $10 \%$ (cGy) & 328.3 & $337(68-524)$ \\
\hline Mean dose (cGy) & 131.6 & $129(33-205)$ \\
\hline \multicolumn{3}{|l|}{ Contralateral lung } \\
\hline D 5\% (cGy) & 38.8 & $31(16-164)$ \\
\hline Mean dose (cGy) & 12.1 & $10(3-44)$ \\
\hline \multicolumn{3}{|l|}{ Skin } \\
\hline D $0.01 \mathrm{~cm} 3$ (cGy) & 2380.1 & $2674(1074-2866)$ \\
\hline \multicolumn{3}{|l|}{ Rib } \\
\hline D $0.01 \mathrm{~cm} 3$ (cGy) & 2317.4 & $2475(978-2766)$ \\
\hline
\end{tabular}


Table 4 Early radiation side effects and cosmetic results

\begin{tabular}{lllll}
\hline & Grade 0 & Grade 1 & Grade 2 & Grade 3-4 \\
\hline $\begin{array}{lllll}\text { Early side effect } \\
\quad\end{array}$ Skin & $21(77.8 \%)$ & $6(22.2 \%)$ & $0(0 \%)$ & $0(0 \%)$ \\
Breast parenchyma & $24(89.9 \%)$ & $3(11.1 \%)$ & $0(0 \%)$ & $0(0 \%)$ \\
Pain & $26(96.6 \%)$ & $1(3.4 \%)$ & $0(0 \%)$ & $0(0 \%)$ \\
& Excellent & Good & Fair & Poor \\
Cosmetic result & & & & \\
$\quad$ Rated by physicians & $17(61.9 \%)$ & $10(30.1 \%)$ & $0(0 \%)$ & $0(0 \%)$ \\
$\quad$ Rated by patients & $16(59.3 \%)$ & $11(40.7 \%)$ & $0(0 \%)$ & $0(0 \%)$ \\
\hline
\end{tabular}

efficacy, feasibility, and quality of life after a 5-year follow-up. But brachytherapy is invasive and needs a highly qualified staff to perform [10-12]. In 2019, Vicini et al. presented the 10 -year results of the NSABP B-39/RTOG 0413 phase III APBI study in the Lancet [41]. The 10-year cumulative incidence of IBTR between APBI and WBI was only $0.7 \%$ (4.6\% vs $3.9 \%$ ) with a hazard ratio (HR) of 1.22 (90\%CI 0.94-1.58), this difference in IBTR was less than $1 \%$ at 10 years, suggesting that APBI is an acceptable option for a proportion of women who undergo BCS. There were no statistically significant differences in late G3-5 toxicities. In the same issue of the Lancet, the long-term results of the RAPID 3D-CRT APBI trial were also presented by Whelan et al. [42]. After 8.6 years of median follow-up, the LR rate was $2.8 \%$ in the WBI, and $3 \%$ in the PBI arm, but the difference was not statistically significant $[\mathrm{HR}=1.27(90 \% \mathrm{CI}, 0.84-1.91)]$. Grade 2 and grade 3 late side effects were $28 \%$ and $4 \%$ in PBI and $12 \%$ and $1 \%$ in the WBI arm, the 7-year fair and poor cosmetic results were $31 \%$ vs $15 \%$, respectively. The five-year results of the Italian prospective randomized study have presented that the 5-year local tumour control was equivalent with APBI or WBI, 1.5\% local recurrence rate in both arms [43]. Concerning acute side effects, the APBI group showed significantly better results in any grade $(p=0.0001)$ and grade 2 or higher $(\mathrm{p}=0.0001)$ cases. APBI with 3D-CRT or IG-IMRT are non-invasive techniques in contrast to iBT.

Recently, CK has emerged as a possible alternative to conventional APBI techniques. CyberKnife offers advantages of iBT and external beam APBI. The dose profile of CK is comparable to brachytherapy because of the steep dose gradient with small PTV volumes, and it is a non-invasive method. The CK respiratory tracking system allows treatment to be delivered while also considering the patient's breath motions. Many publications have noted higher rates of late toxicity and/or poorer cosmetic results following APBI delivered with 3D-CRT or IMRT compared to WBI [14, 18, 37, 44, 45]. Hepel et al. [37] reported $8.3 \%$ rate of grade 3-4 subcutaneous fibrosis after a median follow-up of 15 months. Shah et al. [14] also published a 7.5\% rate of grade 3-4 fibrosis after 5 years. In these studies, the higher rate of late toxicity was probably due to the voluminous irradiated target, since the PTV values were in the range of 175 to $330 \mathrm{~cm}^{3}$. To minimize the amount of the treated volume, we performed real-time image guidance during each fraction. Using the Synchrony system, the CTV-PTV margins could be decreased to $2 \mathrm{~mm}$ obtain a limited mean target volume (PTV EVAL) of $75.7 \mathrm{~cm}^{3}$. In contrast, in our previous APBI study using IGIMRT technique without real-time tracking and using a $5 \mathrm{~mm}$ CTV-PTV margin, the mean treatment volume (PTV EVAL) was $152.6 \mathrm{~cm}^{3}$ which is twice the volume obtained in this study using CK-SAPBI [22].

A very limited number of phase I or II prospective study have been published with CK-SAPBI [30-36]. One of the earliest studies published by Vermuelen et al. in 2011 reported 46 patients treated with CK-SAPBI [31]. The first two patients were treated with 5 fractions of 5 Gy each, thereafter the patients received 10 times 3.4 Gy to the PTV, recommended to the $65-75 \%$ isodose-line. After 12 patients, the prescribed dose was increased to 10 times $3.6 \mathrm{~Gy}$. The mean percent isodose prescription line was $70 \%$ (range, $65-76 \%$ ) to the PTV, the mean PTV was $114 \mathrm{~cm}^{3}$ (range, $39-241 \mathrm{~cm}^{3}$ ). After a mean follow-up of 31 months (range, 6-57 months), no $\mathrm{BC}$ recurrence was recorded. Very mild toxicities occurred, $100 \%$ of the patients had good-excellent cosmesis. Lozza et al. published a pilot study in 2018, they treated 20 patients with CK-SAPBI using the Iris collimator [32]. The total dose was $30 \mathrm{~Gy}$ in 5 consecutive fractions and were prescribed to the isodose line include $95 \%$ of the PTV. After a 2-year median follow-up, no recurrence occurred, a mean $88.1 \mathrm{~cm}^{3}$ PTV was treated with mild acute and late side effects, and more than $80 \%$ of cases ended with excellent cosmetic results. The total patient treatment time comprised patient set-up was around 60 min (range: $35-120 \mathrm{~min}$ ). In 2016, 10 patients received CK-SAPBI in Georgetown University Hospital [30]. A 5 $\mathrm{mm}$ safety margin was added to CTV to generate PTV, and they use the same treatment schedule as previously described (30 Gy in five fractions). The mean prescription isodose line was $80 \%$ to the PTV, and the mean treated PTV was $70 \mathrm{~cm}^{3}$, $100 \%$ of the PTV received the prescription dose (PTV30). After the treatments mild toxicity was reported. At a median follow-up of 1.3 years, no breast events have been documented, and all patients had excellent/good cosmetic results.

There are some potential disadvantages of CK-SAPBI. The impalement of the fiducials is an invasive intervention. Fiducial movement can appear after placement, therefore our practice is to wait at least 1 week following fiducial implantation. CK-SAPBI daily treatment times are lengthened compared to another external beam APBI 10-15 min treatments. In our study, the mean treatment time was 43 min (range: 33$68 \mathrm{~min}$ ). We observed a learning curve meaning a continuously decreasing door to door treatment time as our experience has grown. The smaller treatment volume and less toxicities are the trade-offs for the relatively longer treatment time. 


\section{Conclusions}

SAPBI with $\mathrm{CK}$ is a suitable and practicable technique for the delivery of APBI after BCS for low-risk, St. I-II. IBC. Our early findings are encouraging, CK-SAPBI delivered with four daily fractions is convenient and perfectly tolerated by the patients. Longer follow-up and a higher number of patients are needed to validate the late toxicity and tumour control results.

Acknowledgements Financial support from the 2019 Thematic Excellence Program (TUDFO/51757/2019-ITM) is greatly acknowledged.

Funding Information Open access funding provided by National Institute of Oncology (OOI).

\section{Compliance with Ethical Standards}

Conflict of Interest $\quad$ N. Mészáros, V. Smanykó, T. major, G. Stelczer, L. Jánváry, E. Kovács, M. Bahéri, Z. Zaka, D. Pukancsik, Z. Takácsi-Nagy, C Polgár Z. Zaka, D. Pukancsik, and C. Polgár state that there are no conflicts of interest.

Open Access This article is licensed under a Creative Commons Attribution 4.0 International License, which permits use, sharing, adaptation, distribution and reproduction in any medium or format, as long as you give appropriate credit to the original author(s) and the source, provide a link to the Creative Commons licence, and indicate if changes were made. The images or other third party material in this article are included in the article's Creative Commons licence, unless indicated otherwise in a credit line to the material. If material is not included in the article's Creative Commons licence and your intended use is not permitted by statutory regulation or exceeds the permitted use, you will need to obtain permission directly from the copyright holder. To view a copy of this licence, visit http://creativecommons.org/licenses/by/4.0/.

\section{References}

1. Fischer B, Anderson S, Bryant J et al (2002) Twenty-year follow up of a randomized trial comparing total mastectomy, lumpectomy plus irradiation for the treatment of invasive breast cancer. N Engl J Med 347:1233-1241

2. Veronesi U, Cascinelli N, Mariani L, Greco M, Saccozzi R, Luini A, Aguilar M, Marubini E (2002) Twenty-year follow-up of a randomized study comparing breast-conserving surgery with radical mastectomy for early breast cancer. N Engl J Med 347:1227-1232

3. Darby S, McGale P, Correa C et al (2011) Effect of radiotherapy after breast-conserving surgery on 10-year recurrence and 15 -year breast cancer death: meta-analysis of individual patient data for 10, 801 women in 17 randomised trials. Lancet 378:1707-1716

4. Holland R, Veling SH, Mravunac M et al (1985) Histologic multifocality of tis, T1-2 breast carcinomas. Implications for clinical trials of breast-conserving surgery. Cancer 56(5):979-990

5. Faverly D, Holland R, Burgers L (1992) An original stereomicroscopic analysis of the mammary glandular tree. Virchows Arch A Pathol Anat Histopathol 421(2):115-119

6. Veronesi U, Cascinelli N, Mariani L, Greco M, Saccozzi R, Luini A, Aguilar M, Marubini E (2002) Twenty-year follow-up of a randomized study comparing breast-conserving surgery with radical mastectomy for early breast cancer. N Engl J Med 347(16):1227-1232
7. Nattinger AB, Hoffmann RG, Kneusel RT, Schapira MM (2000) Relation between appropriateness of primary therapy for earlystage breast carcinoma and increased use of breast-conserving surgery. Lancet 356:1148-1153

8. Magee B, Swindell R, Harris M, Banerjee SS (1996) Prognostic factors for breast recurrence after conservative breast surgery and radiotherapy: results of a randomised trial. Radiother Oncol 39: 223-227

9. Fentiman IS, Poole C, Tong D et al (1996) Inadequacy of iridium implant as sole radiation treatment for operable breast cancer. Eur J Cancer 32A:608-611

10. Strnad V, Ott OJ, Hildebrandt G, Kauer-Dorner D, Knauerhase H, Major T, Lyczek J, Guinot JL, Dunst J, Gutierrez Miguelez C, Slampa P, Allgäuer M, Lössl K, Polat B, Kovács G, Fischedick AR, Wendt TG, Fietkau R, Hindemith M, Resch A, Kulik A, Arribas L, Niehoff P, Guedea F, Schlamann A, Pötter R, Gall C, Malzer M, Uter W, Polgár C, Groupe Européen de Curiethérapie of European Society for Radiotherapy and Oncology (GEC-ESTRO) (2016) Accelerated partial breast irradiation (APBI) using sole interstitial brachytherapy versus whole breast irradiation with boost after breast conserving surgery for low risk invasive and is situ carcinoma of the female breast: 5 -year results of a randomised phase 3 non-inferiority trial. Lancet 387:229-238

11. Polgár C, Ott OJ, Hildebrandt G, Kauer-Dorner D, Knauerhase H, Major T, Lyczek J, Guinot JL, Dunst J, Miguelez CG, Slampa P, Allgäuer M, Lössl K, Polat B, Kovács G, Fischedick AR, Fietkau R, Resch A, Kulik A, Arribas L, Niehoff P, Guedea F, Schlamann A, Pötter R, Gall C, Uter W, Strnad V, Groupe Européen de Curiethérapie of European Society for Radiotherapy and Oncology (GEC-ESTRO) (2017) Late side-effects and cosmetic results of accelerated partial breast irradiation with interstitial brachytherapy versus whole-breast irradiation after breastconserving surgery for low-risk invasive and in-situ carcinoma of the female breast: 5 -year results of a randomised, controlled, phase 3 trial. Lancet Oncol 18:259-268

12. Schäfer R, Strnad V, Polgár C, Uter W, Hildebrandt G, Ott OJ, Kauer-Dorner D, Knauerhase H, Major T, Lyczek J, Guinot JL, Dunst J, Miguelez CG, Slampa P, Allgäuer M, Lössl K, Kovács G, Fischedick AR, Fietkau R, Resch A, Kulik A, Arribas L, Niehoff P, Guedea F, Schlamann A, Gall C, Polat B, Wendt TG, Hindemith M, Pötter R, Malzer M (2018) Quality-of-life results for accelerated partial breast irradiation with interstitial brachytherapy versus whole-breast irradiation in early breast cancer after breastconserving surgery (GEC-ESTRO): 5-year results of a randomised, phase 3 trial. Lancet Oncol 19:834-844

13. Formenti SC, Hsu H, Fenton-Kerimian M, Roses D, Guth A, Jozsef G, Goldberg JD, DeWyngaert JK (2012) Prone accelerated partial breast irradiation after breast-conserving surgery: five-year results of 100 patients. Int J Radiat Oncol Biol Phys 84:606-611

14. Shah C, Wilkinson JB, Lanni T, Jawad M, Wobb J, Fowler A, Wallace M, Chen P, Grills IS, Vicini F (2013) Five-year outcomes and toxicities using 3-dimensional conformal external beam radiation therapy to deliver accelerated partial breast irradiation. Clin Breast Cancer 13:206-211

15. Vicini F, Winter K, Wong J, Pass H, Rabinovitch R, Chafe S, Arthur D, Petersen I, White J, McCormick B (2010) Initial efficacy results of RTOG 0319: three-dimensional conformal radiation therapy (3D-CRT) confined to the region of the lumpectomy cavity for stage I/II breast carcinoma. Int J Radiat Oncol Biol Phys 77: $1120-1127$

16. Pashtan IM, Recht A, Ancukiewicz M et al (2012) External beam accelerated partial-breast irradiation using 32 Gy in 8 twice-daily fractions: 5-year results of a prospective study. Int J Radiat Oncol Biol Phys 84:e-271-7

17. Lei RY, Leonard CE, Howell CE et al (2013) Four-year clinical update from a prospective trial of accelerated breast intensity- 
modulated radiotherapy (APBIMRT). Breast Cancer Res Treat 140: 119-133

18. Rodríguez N, Sanz X, Dengra J, Foro P, Membrive I, Reig A, Quera J, Fernández-Velilla E, Pera Ó, Lio J, Lozano J, Algara M (2013) Five-year outcomes, cosmesis, and toxicity with 3-dimensional conformal external beam radiation therapy to deliver accelerated partial breast irradiation. Int J Radiat Oncol Biol Phys 87:10511057

19. Mózsa E, Polgar Cs, Fröhlich G et al (2012) Akcelerált parciális konformális külső emlőbesugárzás emlőmegtartó mütét után - fázis II prospektv klinikai vizsgálat előzetes eredményei. Magy Onkol $56: 235-241$

20. Mózsa E, Mészáros N, Major T, Fröhlich G, Stelczer G, Sulyok Z, Fodor J, Polgár C (2014) Accelerated partial breast irradiation with external beam three-dimensional conformal radiotherapy: 5-year results of a prospective phase II clinical study. Strahlenther Onkol 190:444-450

21. Olivotto IA, Whelan TJ, Parpia S, Kim DH, Berrang T, Truong PT, Kong I, Cochrane B, Nichol A, Roy I, Germain I, Akra M, Reed M, Fyles A, Trotter T, Perera F, Beckham W, Levine MN, Julian JA (2013) Interim cosmetic and toxicity results from RAPID: a randomized trial of accelerated partial breast irradiation using threedimensional conformal external beam radiation therapy. J Clin Oncol 31:4038-4045

22. Mészáros N, Major T, Stelczer G, Zaka Z, Mózsa E, Pukancsik D, Takácsi-Nagy Z, Fodor J, Polgár C (2017) Implementation of image-guided, intensity modulated accelerated partial breast irradiation - three-year results of a phase II clinical study. Strahlenther Onkol Jan 193(1):70-79

23. Mészáros N, Major T, Stelczer G et al (2015) Gyorsított, részleges külső emlőbesugárzás képvezérelt, intenzitásmodulált radioterápiával emlőmegtartó műtét után - Fázis II klinikai vizsgálat előzetes eredményei. Magyar Onkológia 59(2):111-118

24. Vicini F, Arthur D, Polgár C et al (2003) Defining the efficacy of accelerated partial breast irradiation: the importance of proper patient selection, adequate quality assurance and common sense. Int $\mathbf{J}$ Radiat Oncol Biol Phys 57:1210-1213

25. Cs P, Van Limbergen E, Pötter R et al (2010) Patient selection for accelerated partial breast irradiation (APBI) after breast-conserving surgery: Recommendations of the Groupe Européen de Curiethérapie-European Society for Therapeutic Radiology and Oncology (GEC-ESTRO) Breast Cancer Working Group based on clinical evidence (2009). Radiother Oncol 94:264-273

26. Zhang B, Zhu F, Ma X, Tian Y, Cao D, Luo S, Xuan Y, Liu L, Wei $Y$ (2014) Matched-pair comparisons of stereotactic body radiotherapy (SBRT) versus surgery for the treatment of early stage nonsmall cell lung cancer: a systematic review and meta-analysis. Radiother Oncol 112(2):250-255

27. Jorgo K, Ágoston P, Jánváry L et al (2019) Stereotactic body radiation therapy with CyberKnife accelerator for low- and intermediate risk prostate cancer. Magy Onkol 63(1):52-59

28. Bhattacharya IS, Woolf DK, Hughes RJ et al (2015) Stereotactic body radiotherapy (SBRT) in the management of extracranial oligometastatic (OM) disease. Br J Radiol 88(1048): 20140712

29. Wowra B, Muacevic A, Tonn JC et al (2012) CyberKnife radiosurgery for brain metastases. Prog Neurol Surg 25:201-209

30. Obayomi-Davies O, Kole TP, Oppong B et al (2016) Stereotactic accelerated partial breast irradiation for early-stage breast cancer: rationale, feasibility and early experiences using the CyberKnife radiosurgerydelivery platform. Front Oncol 6:129

31. Vermeulen S, Cotrutz C, Morris A et al (2011) Accelerated Partial Breast Irradiation: Using the CyberKnife as the Radiation Delivery Platform in the Treatment of Early Breast Cancer. Front Oncol 1:43
32. Lozza L, Fariselli L, Sandri M et al (2018) Partial breast irradiation with CyberKnife after breast conserving surgery: a pilot study in early breast cancer. Radiat Oncol 13(1):49

33. Xu Q, Chen Y, Grimm J et al (2012) Dosimetric investigation of accelerated partial breast irradiation (APBI) using CyberKnife. Med Phys 39(11):6621-6628

34. Zhen X, Zhao B, Wang Z et al (2017) Comprehensive target geometric errors and margin assessment in stereotactic partial breast irradiation. Radiat Oncol 12(1):151

35. Rahimi A, Thomas K, Spangler A et al (2017) Preliminary results of a phase 1 dose-escalation trial for early-stage breast Cancer using 5 fraction stereotactic body radiation therapy for partial-breast irradiation. Int J Radiat Oncol Biol Phys 98(1):196-205.e2

36. Vermeulen SS, Haas JA et al (2014) CyberKnife stereotactic body radiotherapy and CyberKnife accelerated partial breast irradiation for the treatment of early breast cancer. Transl Cancer Res 3(4): 295-302

37. Hepel JT, Tokita M, MacAusland SG et al (2009) Toxicity of threedimensional conformal radiotherapy for accelerated partial breast irradiation. Int J Radiat Oncol Biol Phys 75:1290-1296

38. Seiler S, Rahimi A, Choudhery S, Garwood D, Spangler A, Cherian S, Goudreau S (2016) Ultrasound-guided placement of gold Fiducial markers for stereotactic partial-breast irradiation. AJR Am J Roentgenol 207(3):685-688

39. Major T, Gutiérrez C, Guix B, van Limbergen E, Strnad V, Polgár C, Breast Cancer Working Group of GEC-ESTRO (2016) Recommendations from GEC ESTRO Breast Cancer Working Group (II): Target definition and target delineation for accelerated or boost partial breast irradiation using multicatheter interstitial brachytherapy after breast conserving open cavity surgery. Radiother Oncol 118:199-204

40. Cox JD, Stetz J, Pajak TF et al (1995) Toxicity criteria of the radiation therapy oncology group (RTOG) and the European Organization for Research and Treatment of Cancer (EORTC). Int J Radiat Oncol Biol Phys 31:1341-1346

41. Vicini F, Cecchini R, White J et al (2019) Long-term primary results of accelerated partial breast irradiation after breast-conserving surgery for early-stage breast cancer: a randomised, phase 3, equivalence trial. Lancet 394(10215):2155-2164

42. Whelan T, Julian J, Levine M et al (2019) External beam accelerated partial breast irradiation versus whole breast irradiation after breast conserving surgery in women with ductal carcinoma in situ and node-negative breast cancer (RAPID): a randomised controlled trial. Lancet 394(10215):2165-2172

43. Livi L, Meattini I, Marrazo L et al (2015) Accelerated partial breast irradiation using intensity-modulated radiotherapy versus whole breast irradiation: 5-year survival analysis of a phase 3 randomised controlled trial. Eur J Cancer 51:451-463

44. Peterson D, Truong PT, Parpia S, Olivotto IA, Berrang T, Kim DH, Kong I, Germain I, Nichol A, Akra M, Roy I, Reed M, Fyles A, Trotter T, Perera F, Balkwill S, Lavertu S, Elliott E, Julian JA, Levine MN, Whelan TJ (2015) Predictors of adverse cosmetic outcome in the RAPID trial: an exploratory analysis. Int J Radiat Oncol Biol Phys 91:968-976

45. Jagsi R, Ben-David MA, Moran JM, Marsh RB, Griffith KA, Hayman JA, Pierce LJ (2010) Unacceptable cosmesis in a protocol investigating intensity-modulated radiotherapy with active breathing control for accelerated partial-breast irradiation. Int J Radiat Oncol Biol Phys 76:71-78

Publisher's Note Springer Nature remains neutral with regard to jurisdictional claims in published maps and institutional affiliations. 